\title{
NUMERICAL ANALYSIS OF LONGITUDINAL REINFORCEMENT EFFECT ON RC SLAB PUNCHING SHEAR RESISTANCE BY STRENGTH AND CRACK PROPAGATION CRITERIA
}

\author{
Oleg V. Kabantsev ${ }^{1}$, Sergey B. Krylov ${ }^{2}$, Sergey V. Trofimov ${ }^{1,2}$ \\ ${ }^{1}$ National Research Moscow State University of Civil Engineering, Moscow, RUSSIA \\ ${ }^{2}$ Research Institute of Concrete and Reinforced Concrete named after A.A. Gvozdev, Moscow, RUSSIA
}

\begin{abstract}
The article deals with the influence of longitudinal reinforcement of the support zone of reinforced concrete slabs on the strength and crack resistance under the criterion for punching failure. The evaluation of impact was carried out by the method of numerical studies based on finite-element computational technologies. The results of physical experiments published in the scientific literature are taken as the basis for the conducted research. The existing provisions of the existing domestic and foreign standards for the calculation of slab reinforced concrete structures according to the criterion for punching failure are considered. The main provisions of the applied finite element approach are presented, verification is performed and the correctness of the applied technique is justified. In the numerical studies, the forecast of strength and crack resistance was done for considered reinforced concrete slab structures; the results of numerical studies were compared with the data from physical experiments and the evaluation results based on the relevant domestic and foreign regulations. According to numerical studies results it was stated that longitudinal reinforcement of the tensile zone of slab structure has a significant impact on both the level of load-bearing capacity and the scheme of crack formation and propagation. The results of the implemented studies justify the necessity to revise the national standards of structural analysis for reinforcement concrete slab structures under the criterion for punching failure.
\end{abstract}

Keywords: modeling, numerical methods, design model, stress-strain state, reinforced concrete structures, punching failure.

\section{ОЦЕНКА ВЛИЯНИЯ ПРОДОЛЬНОГО АРМИРОВАНИЯ НА ПРОЧНОСТЬ И ТРЕЩИНОСТОЙКОСТЬ ЖЕЛЕЗОБЕТОННОЙ ПЛИТЫ ПО КРИТЕРИЮ ПРОДАВЛИВАНИЯ МЕТОДОМ ЧИСЛЕННЫХ ИССЛЕДОВАНИЙ}

\author{
О.В. Кабанцев ${ }^{1}$, С.Б. Крылов ${ }^{2}$, С.В. Трофимов ${ }^{1,2}$ \\ ${ }^{1}$ Национальный исследовательский Московский государственный строительный университет, г. Москва, РОССИЯ \\ ${ }^{2}$ Научно-исследовательский, проектно-конструкторский и технологический институт бетона и железобетона \\ им. А.А. Гвоздева, г. Москва, РОССИЯ
}

\begin{abstract}
Аннотация: В статье рассматривается вопрос влияния продольного армирования приопорной зоны железобетонных плит на прочность и трещиностойкость по критерию продавливания. Оценка влияния выполнена методом численных исследований на основе конечноэлемпентных расчетных технологий. В качестве основы проведенных исследований приняты результаты физических экспериментов, опубликованных в научной литературе. Рассмотрены существующие положения действующих отечественных и зарубежных норм по расчету плитных железобетонных конструкций по критерию продавливания. Представлены основные положения используемого конечноэлементного подхода, выполнена верификация и обоснована корректность применяемой методики. В выполненных численных исследованиях получен прогноз прочности и трещиностойкости рассмотренных вариантов железобетонных плитных конструкций, представлено сравнение полученных результатов численных исследований с данными физических экспериментов и результатами оценки на основе действующих отечествен-
\end{abstract}


ных и зарубежных норм. По результатам численных исследований установлено, что продольное армирование растянутой зоны плитных конструкций оказывает существенное влияние как на уровень несущей способности, так и на схему формирования и развития трещин. Результатами выполненных исследований обосновывается необходимость совершенствования отечественных норм по расчету железобетонных плитных конструкций по критерию продавливания.

Ключевые слова: моделирование, численные методы, расчетная модель, напряженно-деформированное состояние, железобетонные конструкции, продавливание.

\section{INTRODUCTION}

The studies of the punching failure phenomenon for reinforced concrete structures has a centennial timeline. Thus, one of the first domestic books dedicated to structural analysis and design of reinforced concrete structures [1] contains guidelines for design methods of supporting joints of slab structures as well as the number of structural requirements for the dimensions of zone adjacent to core support in reinforced concrete slabs (pp. 19-22). In the early XXth century, the book [2] containing guidelines for structural analysis and design of supporting joint of floor slabs, with probable manifestation of punching failure, was widely used in the engineering practice for reinforced concrete structures ( $\mathrm{pp}$. 524-525).

The studies of reinforced concrete structures carried out in the second half and in the late XX century have taken a broadside approach to the issue of punching failure. Thus, in the works of Zalesov A.S. [3, 4, 5], Karpenko N.I. [6, 7] and others [8-10], as well as of some foreign researchers (see, for example [11-19]), the various aspects of punching failure for reinforced concrete slabs are factored in. The studies implemented by Klovanich S.Ph. and Shekhovtsov V.I. constitute those few works investigating cruciform and angle shape (the research results are outlined in the monograph [20]). It is shown that punching failure is characterized by rather complicated mechanisms defined not only (and not so much) by the performance of the concrete body of a structure but by the impact of both longitudinal and transverse reinforcement in the support zones.
A number of models describing the performance of slabs under the punching failure have been proposed (the detailed analysis of models is presented in [5]).

Along with that, there is commonly held opinion that structural failure under the punching failure mechanism is nothing other than a particular case of sloping section failure of reinforced concrete structure. However, the works [21, 22] prove that such an approach is not the correct one. Thus, punching failure phenomenon should be thoroughly studied, with special consideration given to its complicated mechanism.

When doing numerical prediction of the bearing capacity of reinforced concrete slabs under the criterion for punching failure, the most significant aspect is the factor of longitudinal reinforcement of tensile zone of slab structures. However, the present regulations and codes of practice do not examine the factor of longitudinal reinforcement. So, it is worth considering the fundamental statements of domestic and foreign regulations related to strength prediction of a reinforced concrete structure without transverse reinforcement of support zones.

Analysis of the current normative approach to the structural design of reinforced concrete slabs under the criterion for punching failure.

The following regulations of codes of practice have been considered: Construction Rules CR 63.13330.2018 (hereinafter CR63) [23], EN 19921-1 Eurocode 2 (hereinafter EC2) [24] and Model Code 2010 (hereinafter MC 2010) [25].

In the $\boldsymbol{E C} 2$ [24], impact puncture strength, regardless of transverse reinforcement (VRd,c) is estimated under the formula (1). 
Numerical Analysis of Longitudinal Reinforcement Effect on Rc Slab Punching Shear Resistance by Strength and Crack Propagation Criteria

$$
\mathrm{V}_{\mathrm{Rd}, \mathrm{c}}=\frac{0.18}{\gamma_{\mathrm{c}}} \cdot \mathrm{b}_{0, \mathrm{EC}} \cdot \mathrm{d} \cdot \mathrm{k} \cdot\left(100 \cdot \rho \cdot \mathrm{f}_{\mathrm{c}}\right)^{1 / 3} \geq \mathrm{v}_{\text {min }} \cdot \mathrm{b}_{0, \mathrm{EC}} \cdot \mathrm{d}
$$

where: $\gamma_{c}$ - reliability factor of concrete under compression; $b_{O E C}$ - perimeter of the effective cross section circuit with rounded corners at the $2 d$ distance from the loaded area; $d$-effective operating height of cross section; $f_{c}$ - compressive strength of concrete; $\rho$-coefficient of longitudinal reinforcement (the maximum value of $2 \%$ ); $k$ - coefficient factoring in scale effect (relative reduction of impact puncture strength at the increase in its effective operating height of cross section), is calculated as: $\mathrm{k}=1-\sqrt{200 / \mathrm{d}} ; V_{\min }$ minimum impact puncture strength that makes allowance only for tensile strength of concrete and scale effect, is calculated under the formula (2).

$$
\mathrm{v}_{\min }=0.035 \cdot \mathrm{k}^{3 / 2} \cdot \mathrm{f}_{\mathrm{c}}^{1 / 2}
$$

It should be noted that when evaluating bearing capacity of reinforced concrete slabs under the criterion for punching failure, EC2 factor in normal stresses in concrete along the slab orthogonal axes ( $\mathrm{Y}$ и Z) in critical cross sections. The mentioned normal stresses may appear due to, for example, prestressed longitudinal reinforcement or due to the forces formed in the bearing structures exposed to the loads. The normal stresses factor is taken into account by insertion of additive component $\sigma_{c p}$ into the right side of the formula (1).

$$
\sigma_{\mathrm{cp}}=\frac{\sigma_{\mathrm{cy}}+\sigma_{\mathrm{cz}}}{2}
$$

where: $\sigma_{c y}$ and $\sigma_{c z}-$ axis stresses faired along the span width for the intermediate columns and along the width of calculated perimeter for edge columns. Caused by external actions or stretching, stresses are taken into consideration.

Factoring in normal stresses in the concrete of support zone, the formula (1) takes the following form:

$$
\mathrm{V}_{\mathrm{Rd}, \mathrm{c}}=\frac{0.18}{\gamma_{\mathrm{c}}} \cdot \mathrm{b}_{0, \mathrm{EC}} \cdot \mathrm{d} \cdot \mathrm{k} \cdot\left(100 \cdot \rho \cdot \mathrm{f}_{\mathrm{c}}\right)^{1 / 3} \geq \mathrm{v}_{\text {min }} \cdot \mathrm{b}_{0, \mathrm{EC}} \cdot \mathrm{d}+0.1 \cdot \sigma_{\mathrm{qp}}(4)
$$

In the $\mathbf{M C 2 0 1 0}$ [25], impact puncture strength regardless of transverse reinforcement $\left(V_{R d, c}\right)$ makes allowance for angular rotation of the slab support zone $\psi$ and is estimated under the formula (5).

$$
\mathrm{V}_{\mathrm{Rd}, \mathrm{c}}=\mathrm{k}_{\psi} \cdot \frac{\sqrt{\mathrm{f}_{\mathrm{c}}}}{\gamma_{\mathrm{c}}} \cdot \mathrm{b}_{0} \cdot \mathrm{d}_{\mathrm{v}}
$$

where: $\gamma_{c}$ - reliability factor of concrete under compression; $b_{0}$ - perimeter of the effective cross section circuit with rounded corners at the $0.5 d_{v}$ distance from the loaded area; $d_{v}$ - effective operating height of cross section; $f_{c}$ - compressive strength of concrete; $k_{\psi}$ - coefficient factoring in the angle of slab rotation $\psi$, is calculated under the formula (6).

$$
\mathrm{k}_{\psi}=\frac{1}{1.5+0.9 \cdot \mathrm{k}_{\mathrm{dg}} \cdot \psi \cdot \mathrm{d}_{\mathrm{v}}}
$$

where: $k_{d g}$-coefficient factoring in the grain size of coarse aggregate; $\psi$ - the angle of slab rotation, estimated by the formula (7) for the recommended MC2010, the approximation level II.

$$
\psi=1.5 \cdot \frac{r_{c}}{d_{v}} \cdot \frac{f_{y}}{E_{c}} \cdot\left(\frac{m_{s}}{m_{R}}\right)^{1.5}
$$

where: $r_{s}$ - the distance from the point where the radial moment of flection is equal to 0 (for the tested samples, the distance from the sample center to the fixing point); $E_{s}$ - reinforcement modulus of elasticity; $f_{v}$ - yield point of reinforcement; $m_{s}$ - moment of flection in the slab exposed to the load, averaged at the width $b_{s}=1.5 r_{s} ; m_{R}$-bending strength of the slab, estimated by the formula (8).

$$
m_{R}=\rho \cdot d_{v}^{2} \cdot f_{y} \cdot\left(1-\frac{\rho \cdot f_{y}}{2 \cdot f_{c}}\right)
$$

It bears mentioning a significant peculiarity of the MC2010 [25], i.e. the application of so-called approach in the form of the Levels of Approximation (Level of Approximation, hereinafter LoA) - see figure 1 . 
LoA I represents preliminary evaluation of bearing capacity of a floor slab support zone at punching failure on the hypothesis that longitudinal reinforcement has reached yield point at the moment of failure.

LoA II is distinguished from LoA I by refinement of the reinforcement use factor for longitudinal reinforcement at the moment of punching failure when the approximate data could be obtained analytically on the base of punching force and the parameters of longitudinal reinforcement. LoA III presupposes specifying strain capacity of reinforcement by dimensional linear calculation, and the level IV provides for determining the angle of rotation directly from the non-linear slab design (including the slab modelling by shell structural elements).

The authors of the MC 2010 [25] recommend the application of the level I (LoA I) for preliminary calculations. LoA II is recommended for designing the most part of new structures with the regular column grid, LoA III is recommended for the analysis of existing structures and the structures with irregular geometry; whereas LoA IV is a good practice for particular cases or for more specified evaluation of the longitudinal floor slab to column joint.

In the CP 63.13330.2018 [23], bearing capacity of reinforced concrete slab without transverse reinforcement is calculated by the formula (9).

$$
F_{b, u l t}=R_{b t} \cdot A_{b}
$$

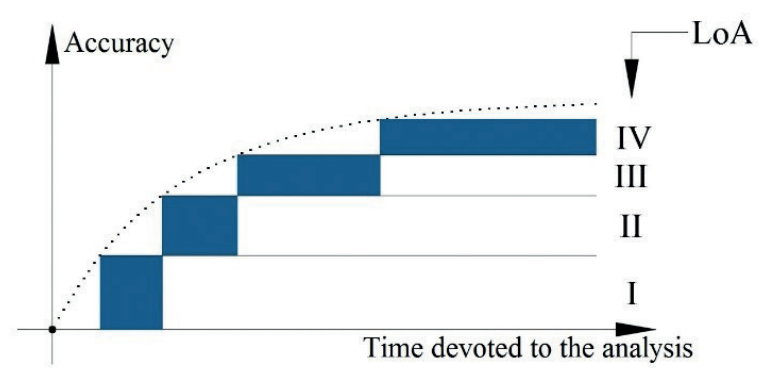

Figure 1. Accuracy of normative evaluation as a function of time spent on the calculation of different approximation levels. where: $F_{b, u l t}$ - the ultimate force taken by concrete; $R_{b t}$ - tensile strength of concrete; $A_{b}$ - area of the effective cross section located at the distance of $0.5 h_{0}$ form the border of the concentrated force application area $F$ with the operating height of the section $h_{0}$. The area $A_{b}$ is determined by the formula (10).

$$
F_{b, u l t}=R_{b t} \cdot A_{b}
$$

where: $u$-perimeter of the effective cross section circuit.

Outlined in domestic and foreign codes and regulations, the comparative analysis of bearing capacity rating for reinforced concrete slabs under the criterion for punching failure has shown that allowance had been made for the factor $f i b$ regulations [25] and in the $E C$ codes [24]. The given approach seems rather logical as longitudinal reinforcement of tensile zone of reinforced concrete slab at the support zone has an immediate impact on crack formation and propagation in the zone of superior limits of stress for slab support zone. In its turn, bearing capacity of support joint depends on the crack formation processes under the criterion for punching failure. Thus, the detailed study of the impact of the tensile zone longitudinal reinforcement on the value of bearing capacity of reinforced concrete slabs under the criterion for punching failure is regarded as the relevant task. The solution of this task will enable to refine current domestic codes and regulations.

\section{OBJECTIVE AND METHOD OF RESEARCH}

\section{Description of finite element computer system designated for numerical methods.}

The study of stress-strain state, bearing capacity and crack formation has been carried out by means of computer system (CS) ATENA [26].

Structural modeling by ATENA, generally speaking, is done based on specific properties of materials: concrete is modelled by the volume finite elements; whereas reinforcing members are usually modelled as rods. However, for some 
Numerical Analysis of Longitudinal Reinforcement Effect on Rc Slab Punching Shear Resistance by Strength and Crack Propagation Criteria

cases, it is quite conceivable that reinforcement modelling is done by means of distributed reinforcement, when steel ration of concrete is set. The user models concrete-to-steel bond by means of introduction of special bonds performing under the desired law. In addition, the software complex allows modelling of other materials, such as steel, soils, mason work, fiber-reinforced concretes, ultrahigh-strength concretes, carbon fiber and others.

Computer software ATENA comprises special constitutive models for finite element analysis of concrete and reinforced concrete structures. In compliance with the official reference book describing the software theoretical basis [26], a model of concrete combines theory of plastic behavior equation (under compression) and fracture mechanics (under tension). The model applies the criterion of superior stress limits for evaluation of strength, exponential softening law, when a crack could be specified as turning or restrained one.

Under tension, concrete behavior is simulated by non-linear methods of fracture mechanics combined with the smeared crack model. The main parameters of the given approach are the following: concrete tensile strength, pattern and shape of crack formation, and fracture energy. The phenomenon of crack formation is described by the smeared crack model in the form of crack band [27]. In its general form, the law of crack formation is presented at the figure 2 .

Crack opening width is calculated as full movement within the cracked element [26]. The width $\mathrm{w}$ is determined by the formula (11).

$$
w=\varepsilon \cdot L_{t}
$$

where: $\varepsilon$-average relative deflorations of cracked finite element at the lack of strains; $L_{t}-$ the size of finite element.

As demonstrated at the figure 3 , the process of crack formation could be divided into three stages. So-called uncracked stage corresponds to the performance of the material before reaching its ultimate tensile strength. Crack formation occurs in the zone of a potential crack as tension stresses are being reduced in this area. Then crack opening continues at zero tension stresses occurring at the crack tip.

CS ATENA gives expansive opportunities to set the loads and effects on the researched finite element model. Thus, there exist conventional static and dynamic loading as well as the effect forming due to creep, contraction, materials degradation and corrosion.

For plasticity model describing concrete compression, the Menetrèy-Willam failure criterion is applied. Separately, the algorithm combining the crack formation model and plasticity model has been developed. The principal peculiarity of CS ATENA is as follows: though two mentioned models are simulated independently, they are jointly applied in computation.

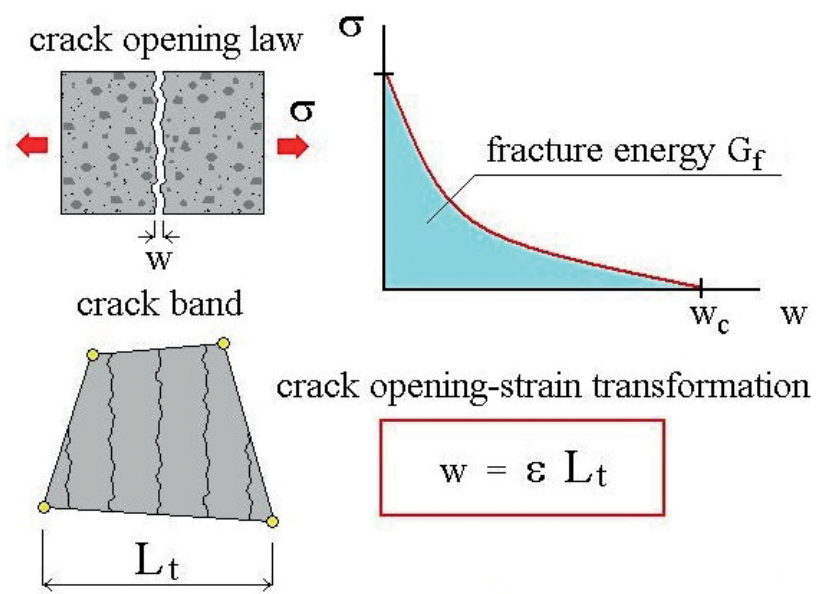

Figure 2. The law of crack formation in a general form CS ATENA according to the [27].

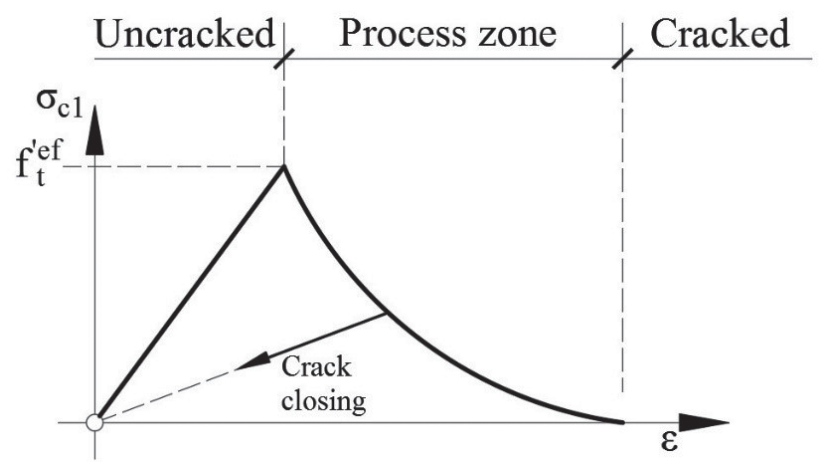

Figure 3. The stages of crack formation and propagation CS ATENA according to [27]. 
The other specific feature of concrete model is the use of so-called restrictions of failure strain isolation. The given notion is applied for identifying discrete failure planes, independent of finite element grid.

For the case of tension, these planes are presented by cracks, for the case of compression - by the areas of grinding respectively. In the computed model, these discrete areas of failure have the dimensions independent of the element dimensions. For this particular reason, failure planes are presented in the model as the planes independent of the finite element grid dimensions. For the case of tensile rupture, the present approach is known as the crack band model mentioned above. In the CS ATENA, the similar approach is also applied for compression failure. Thus, restrictors of failure strain isolation enable to eliminate two principal shortcomings of traditional finite element concrete model, i.e. the effect of size and orientation of finite element grid on the result.

The applied concrete model enables to consider such phenomena as:

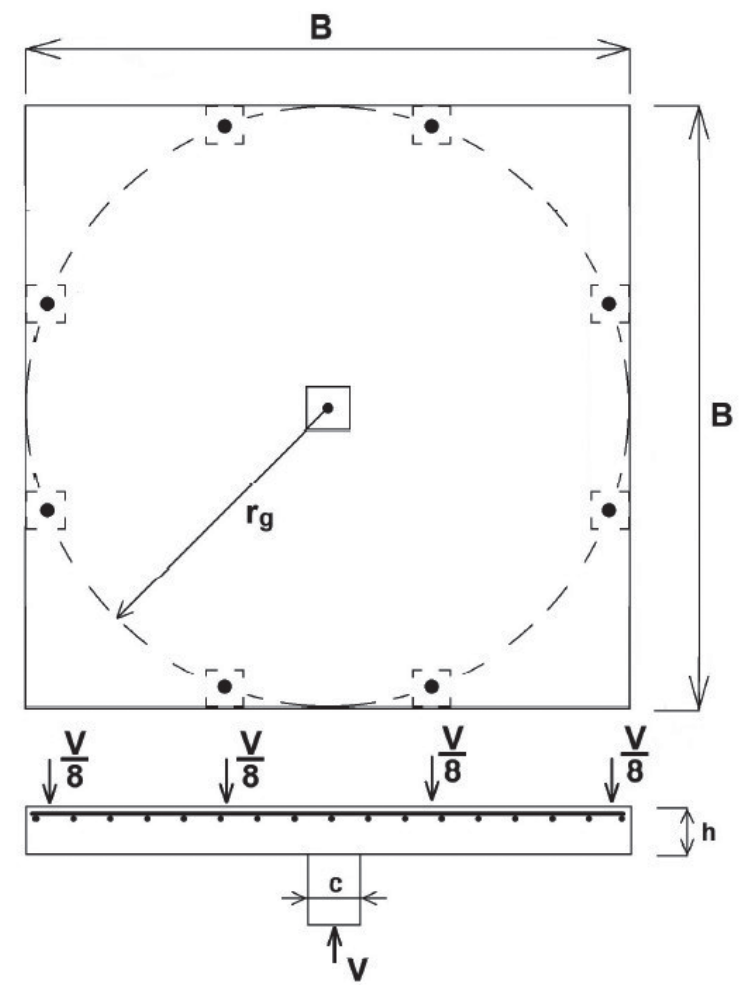

Figure 4. Geometry of the tested samples under the [29].
- non-linear behavior of a material exposed to tension and compression;

- crack formation and crack opening/closing;

- lowering of compressive and shear strength occurred after cracking in either direction;

- enhancement of concrete strength properties due to two-three-side squeeze reduction;

- mesh of crack edges in shear;

- grinding at the high degree of squeeze reduction; - crack closing occurred due to material crushing in other directions.

Applying smeared crack model as an integral part of the above-mentioned constitutive model of concrete behavior allows accurate computation and visualization of discrete cracks propagation. Moreover, as claimed by the software developers [28], the present model compares favorably in accuracy with the models realizing discrete cracks.

\section{Verification of the adopted tool of numerical study (CS ATENA).}

Verification of the research tool (CS ATENA) has been implemented by the method of comparative analysis of the results obtained by finite element calculation of CS ATENA models. The models correspond to the published results of the physical experiments carried out in the University of Lausanne [29]. The tests were done in the framework of the study of reinforced concrete slab-to column joint exposed to punching failure at the low factor of longitudinal reinforcement in slabs (Figure 2). For all patterns, the samples were reinforced only by longitudinal reinforcement. The samples' characteristics are demonstrated in the table 1 .

Additional parameters for concrete, that are required for numerical calculations, have been obtained on the basis of experimental compression strength by means of the equation from MC 2010 and factoring in given experimental parameters. By analogy with [18], there have been done test calculations of the models corresponding to [29]. The correlation results of verification computation $\left(V_{s i m, \text { ATENA }}\right)$ and the data of physical experiments $\left(V_{e x}\right)$ are given in the table 2 . In 
Numerical Analysis of Longitudinal Reinforcement Effect on Rc Slab Punching Shear Resistance by Strength and Crack Propagation Criteria

addition, for reference only, the table 2 gives the computation results under the codes and regulations $[23,24,25]$.

The analysis of numerical studies of bearing capacity of concrete slab with the reinforced tensile zone under the criterion for punching failure implemented by CS ATENA exhibits good correlation with the results of physical tests, i.e. average deviation from the physical test data figures up to $7 \%$. Thus, verification of CS ATENA for the purpose of further investigation is fulfilled.

\section{RESEARCH RESULTS}

\section{Description of the model of reinforced concrete slab for numerical studies.}

Numerical studies have been implemented with the purpose to assess to impact of longitudinal reinforcement of the tensile zone for reinforced concrete slab on the value of bearing capacity under the criterion for punching failure. In order to carry out investigation for the punching failure scenario, design diagram of slab-to-column joint has been developed.

Table 1

\begin{tabular}{|c|c|c|c|c|c|c|c|c|c|c|c|}
\hline \multirow[b]{2}{*}{ Sample } & \multirow[b]{2}{*}{$\begin{array}{l}B, \\
m\end{array}$} & \multirow[b]{2}{*}{$\begin{array}{l}C, \\
m\end{array}$} & \multirow[b]{2}{*}{$\begin{array}{l}h, \\
m\end{array}$} & \multirow[b]{2}{*}{$\begin{array}{c}h_{0} \\
m\end{array}$} & \multirow[b]{2}{*}{$\begin{array}{l}r_{g} \\
m\end{array}$} & \multirow{2}{*}{$\begin{array}{l}\text { Parameters of longitudi- } \\
\text { nal reinforcement of ten- } \\
\text { sile zone: } \\
\text { diameter }(\mathrm{mm}) / \text { spacing } \\
(\mathrm{mm})\end{array}$} & \multicolumn{5}{|c|}{ Model's parameters } \\
\hline & & & & & & & $\begin{array}{l}\rho, \\
\%\end{array}$ & $\begin{array}{c}f_{c}, \\
M P a\end{array}$ & $\begin{array}{l}R_{b t} \\
M P a\end{array}$ & $\begin{array}{l}d_{g}, \\
m m\end{array}$ & $\begin{array}{c}f_{y}, \\
M P a\end{array}$ \\
\hline PG1 & 3 & 0.26 & 0.25 & 0.21 & 1.5 & $\emptyset 20 / 100$ & 1.5 & 27.6 & 2.4 & 16 & 573 \\
\hline PG2 & 3 & 0.26 & 0.25 & 0.21 & 1.5 & $\emptyset 10 / 150$ & 0.25 & 40.5 & 3.2 & 16 & 552 \\
\hline PG3 & 6 & 0.52 & 0.5 & 0.456 & 2.85 & $\emptyset 16 / 135$ & 0.33 & 32.4 & 2.7 & 16 & 520 \\
\hline PG4 & 3 & 0.26 & 0.25 & 0.21 & 1.5 & $\emptyset 10 / 150$ & 0.25 & 32.2 & 2.7 & 4 & 541 \\
\hline PG5 & 3 & 0.26 & 0.25 & 0.21 & 1.5 & $\emptyset 10 / 115$ & 0.33 & 29.3 & 2.5 & 4 & 555 \\
\hline PG7 & 1.5 & 0.13 & 0.125 & 0.1 & 0.75 & $\emptyset 10 / 105$ & 0.75 & 34.7 & 2.8 & 16 & 550 \\
\hline PG8 & 1.5 & 0.13 & 0.125 & 0.117 & 0.75 & $\emptyset 8 / 155$ & 0.28 & 34.7 & 2.8 & 16 & 525 \\
\hline PG9 & 1.5 & 0.13 & 0.13 & 0.117 & 0.75 & $\emptyset 8 / 196$ & 0.22 & 34.7 & 2.8 & 16 & 525 \\
\hline PG10 & 3 & 0.26 & 0.25 & 0.21 & 1.5 & $\emptyset 10 / 115$ & 0.33 & 28.5 & 2.5 & 16 & 577 \\
\hline PG11 & 3 & 0.26 & 0.25 & 0.21 & 1.5 & $\emptyset 16 / 18 / 145$ & 0.75 & 31.5 & 2.7 & 16 & 570 \\
\hline
\end{tabular}

Notes: designators in the table 1 are accepted in compliance with $[24,25]$ - see the section 1.

Table 2

\begin{tabular}{|c|c|c|c|c|c|c|c|}
\hline $\mathrm{N}$ & Sample & $\begin{array}{l}\mathrm{V}_{\mathrm{ex}}, \\
\mathrm{kN}\end{array}$ & $\begin{array}{l}\mathrm{V}_{\text {sim }}, \\
\text { ATENA, } \\
\mathrm{kN}\end{array}$ & $\frac{\mathrm{V}_{\mathrm{ex}}-\mathrm{V}_{\mathrm{sim}, \mathrm{ATENA}}}{\mathrm{V}_{\mathrm{ex}}} \cdot 100 \%$ & $\begin{array}{c}\mathrm{V}_{\mathrm{Rd}, \mathrm{c}}[25] \\
\mathrm{kN}\end{array}$ & $\begin{array}{c}\mathrm{V}_{\mathrm{Rd}, \mathrm{c}} \\
{[24],} \\
\mathrm{kN}\end{array}$ & $\begin{array}{c}\mathrm{F}_{\mathrm{b}, \mathrm{ult}}[23] \\
\mathrm{kN}\end{array}$ \\
\hline 1 & PG1 & 1023 & 919.5 & 10.12 & 841 & 950 & 947.5 \\
\hline 2 & PG2 & 440 & 434.2 & 1.32 & 420 & 594 & 1263.36 \\
\hline 3 & PG3 & 2153 & 2209 & -2.60 & 1730 & 2340 & 4806.6 \\
\hline 4 & PG4 & 408 & 419.9 & -2.92 & 344 & 550 & 1066 \\
\hline 5 & PG5 & 550 & 551.7 & -0.31 & 455 & 583 & 987 \\
\hline 6 & PG7 & 241 & 290.4 & -20.50 & 197 & 189 & 257.6 \\
\hline 7 & PG8 & 140 & 146.2 & -4.43 & 137 & 178 & 323.7 \\
\hline 8 & PG9 & 115 & 117 & -1.74 & 109 & 165 & 323.7 \\
\hline 9 & PG10 & 540 & 571.1 & -5.76 & 454 & 577 & 987 \\
\hline 10 & PG11 & 763 & 922.5 & -20.90 & 682 & 788 & 1066 \\
\hline
\end{tabular}



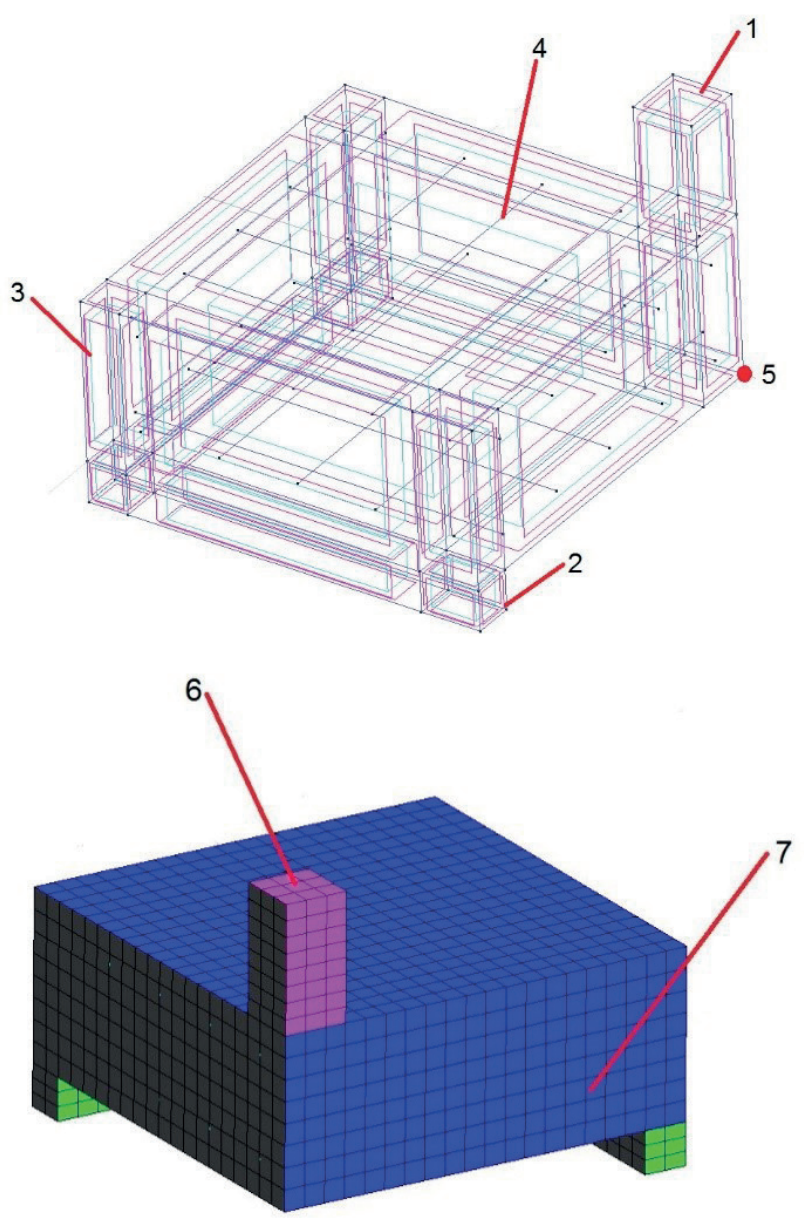

Figure 5. 3D (to the left) and finite model (to the right) model for numerical studies done by CS ATENA.

where: 1 - column; 2 - bearing support;

3 -floor slab; 4 - reinforcement rods;

5 - monitoring point for displacement along the vertical axis; 6 - point of load application; 7 - sample fixture along the symmetry axis.
Design diagram represents $1 / 4$ of support zone of reinforced concrete slab (fig. 5). Longitudinal reinforcement of tensile and compressed zones of the slab has been simulated by means of rod finite elements. The diameter and spacing of rods have been adopted in a such way that sample fracture occurred due to punching load and not on the account of slab bending; or combined fracture took place. Slab load has been transferred via the column in geometrical center of the slab. There has been simulated sample supporting that occurred along the circuit on the rectangular distribution frame. The column material has been taken as elastic one, with concrete modulus of elasticity, to simplify design diagram. All the parameters that are required for describing concrete performance under MC 2010 [25] have been calculated on the basis of cube strength of concrete. Slab, column and support structure have been simulated by volume finite elements. For the design diagram, volume finite elements have taken shape of rectangular prisms with the dimensions $25 \times 25 \times 25 \mathrm{~mm}$.

The main parameters of numerical studies are given in the table 4 .

The results of numerical studies of bearing capacity for reinforced concrete slab factoring in longitudinal reinforcement in comparison with the results of calculation under the current codes and regulations $[23,24,25]$ are outlined in the table 5 and at the figures 6-8.

The analysis of the results obtained by means of numerical studies enables to state the number of

Table 4

\begin{tabular}{|c|c|c|c|c|c|c|c|c|c|}
\hline Sample & $\begin{array}{c}b, \\
\mathrm{~m}\end{array}$ & $\begin{array}{c}h, \\
\mathrm{~m}\end{array}$ & $\begin{array}{c}h_{0}, \\
\mathrm{~m}\end{array}$ & $\begin{array}{c}\text { Reinforcement, } \\
\text { diameter } \\
(\mathrm{mm}) / \text { spacing }(\mathrm{mm})\end{array}$ & $\rho, \%$ & $\begin{array}{c}f_{c}, \\
\mathrm{MPa}\end{array}$ & $\begin{array}{c}R_{b t,} \\
\mathrm{MPa}\end{array}$ & $\begin{array}{c}d_{g}, \\
\mathrm{~m}\end{array}$ & $\begin{array}{c}f_{y,} \\
\mathrm{MPa}\end{array}$ \\
\hline $\mathrm{P} 1$ & 0.15 & 0.2 & 0.163 & $\emptyset 10 / 100$ & 0.48 & 22.4 & 1.78 & 20 & 500 \\
\hline $\mathrm{P} 2$ & 0.15 & 0.2 & 0.163 & $\emptyset 14 / 100$ & 0.94 & 22.4 & 1.78 & 20 & 500 \\
\hline $\mathrm{P} 3$ & 0.15 & 0.2 & 0.163 & $\emptyset 16 / 100$ & 1.23 & 22.4 & 1.78 & 20 & 500 \\
\hline $\mathrm{P} 4$ & 0.15 & 0.2 & 0.163 & $\emptyset 20 / 100$ & 1.93 & 22.4 & 1.78 & 20 & 500 \\
\hline
\end{tabular}




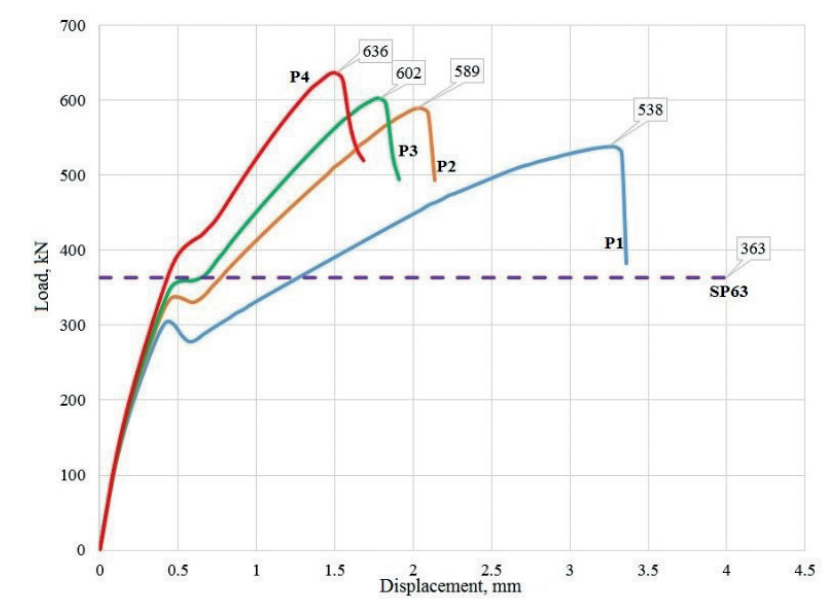

Figure 6. Deformation curve for the calculation models and the values of ultimate loading $(\mathrm{kN})$. new aspects in the pattern of formation of stressstrain state for concrete slab with longitudinal reinforcement of the tensile zone:

1. Longitudinal reinforcement of concrete tensile zone blocks formation, propagation and opening of cracks in the given zone. The main crack volume is formed in the tensile zone of concrete that gives grounds to determine a pattern on joint fracture under the punching failure mechanism predominately.

2. Stresses in the reinforcing rods of concrete tensile zone is lowered with the increase in reinforcing rod diameter. At the same time, the level of bearing capacity of the joint under the criterion for punching failure is augmenting. Thus, increase in the ratio of longitudinal reinforcement of concrete tensile zone ensures significant enhancement of reinforced concrete slab under the criterion for punching failure.

Table 5

\begin{tabular}{|c|c|c|c|c|c|}
\hline Sample & $\begin{array}{c}\mathrm{V}_{\text {sim, }} \\
\text { ATENA, } \\
\mathrm{kN}\end{array}$ & $\begin{array}{c}\mathrm{F}_{\mathrm{b}, \mathrm{ult}} \\
{[23],} \\
\mathrm{kN}\end{array}$ & $\begin{array}{c}\mathrm{V}_{\mathrm{Rd}, \mathrm{c}} \\
{[24],} \\
\mathrm{kN}\end{array}$ & $\begin{array}{c}\mathrm{F}_{\mathrm{b}, \mathrm{ult}}-\mathrm{V}_{\text {sim,ATENA }} \\
\mathrm{F}_{\mathrm{b}, \mathrm{ult}}\end{array}$ & $\begin{array}{c}\text { Stresses arising in rein- } \\
\text { forcement at fracture } \\
\text { point under CS ATENA, } \\
\mathrm{MPa}\end{array}$ \\
\hline P1 & 538 & 363 & 343 & -48.21 & 493 \\
\hline P2 & 589 & 363 & 430 & -62.26 & 346 \\
\hline P3 & 602 & 363 & 467 & -65.84 & 277 \\
\hline P4 & 636 & 363 & 467 & -75.21 & 200 \\
\hline
\end{tabular}

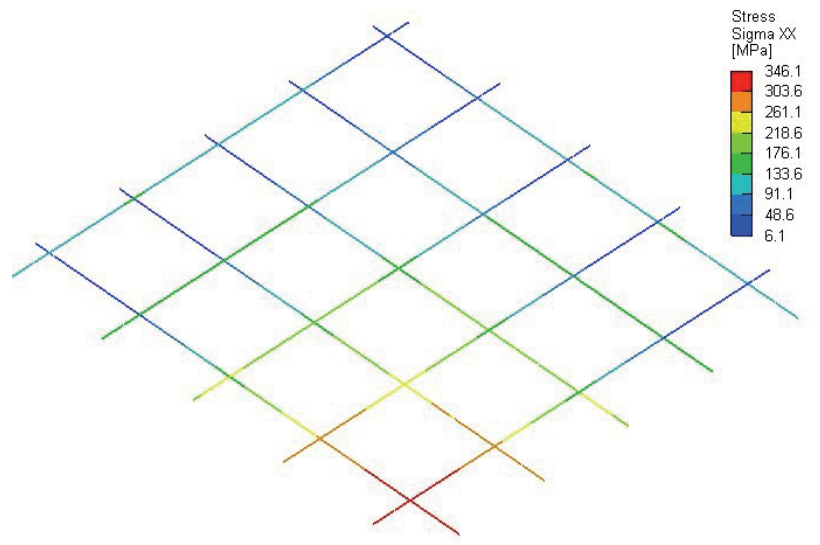

Figure 7. Stresses in the reinforcement of concrete tensile zone at fracture point for the sample P2.

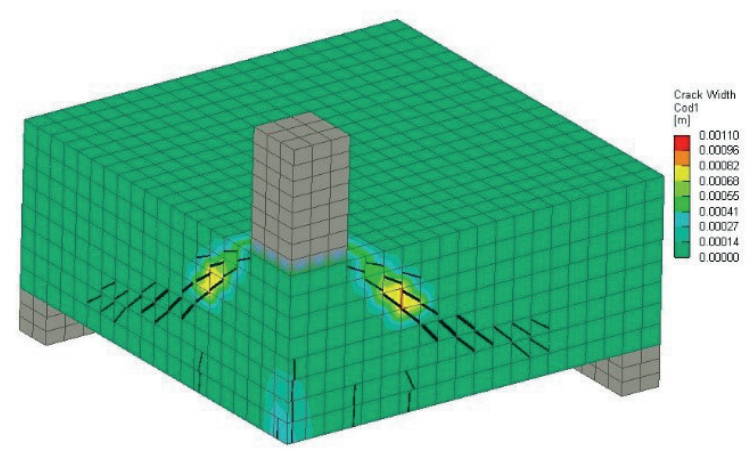

Figure 8. Representative pattern of crack formation in the sample $P 2$ at the fracture point. 
3. In domestic codes and regulations, the lack of clauses allowing for the factor of longitudinal reinforcement when determining bearing capacity of reinforced concrete slabs under the criterion for punching failure should be regarded as the main shortcoming. Thus, codes regulating analysis and design of reinforced concrete structures require further improvement.

\section{CONCLUSION}

The implemented research demonstrates significant impact of longitudinal reinforcement of concrete tensile zone on the value of bearing capacity of the support joint under the criterion for punching failure that until the present time had not been evidenced in the current national codes. The results of investigation proved plausible proof that the issue of the pattern of stress-strain state formation in the support zone of reinforced concrete slabs had not been studied thoroughly. It is quite evident that the mechanisms defining the level of bearing capacity of the support zone have been studied at a lesser extent than the conditions affecting bearing capacity of reinforced concrete slabs under standard cross-section. The patterns of formation and developments of local damages of reinforced concrete slabs in the support zones should be thoroughly studied under two mechanisms - bending and punching failure. Setting standards for bearing capacity of the support zone of reinforced concrete structures requires further improvement.

\section{REFERENCES}

1. Lakhtin N.K., Kashkarov N.A. Reinforced concrete. Allowance in 3 parts for students, engineers and technicians in the design and implementation of reinforced concrete structures. Part III. Grounds for the calculation of reinforced concrete structures. - Moscow.: Gosudarstvennoye tekhnicheskoye izdatel'stvo, 1925. - p. 161.

2. Zalinger R. Reinforced concrete. His calculation and design. The fifth edition. Stereotype - Moscow.: Gosudarstvennoye nauchno-tekhnicheskoye izdatel'stvo, 1931. - p. 671.

3. ZalesovA.S.,Ermuhanov K.E., Kachanovskii S.G. Breakdown of reinforced concrete slabs. Issledovaniya zhelezobetonnykh konstruktsiy pri staticheskikh, povtornykh i dinamicheskikh vozdeystviyakh - Moscow.: NIIZHB Gosstroya SSSR, 1984. - pp. 17-22.

4. Zalesov A.S., Ermuhanov K.E., Mombekov I.A. Strength of plates with shearl reinforcement for punching // Beton i zhelezobeton, Moscow, 1990, №6. - pp. 23-24.

5. Zalesov A.S. Design and calculation of reinforced concrete monolith buildings Moscow: 2010. - p. 279.

6. Karpenko N.I., Karpenko S.N. Practical technique for calculating reinforced concrete slabs for punching through various schemes // Beton i zhelezobeton, Moscow, 2012, №5. - pp. 10-16.

7. Karpenko N.I., Karpenko S.N. To the construction of a general methodology for calculating reinforced concrete slabs for punching taking into account the effect of moments // Vestnik MGSU, Moscow, 2011,V. 2, №3. - pp. 86-91.

8. Trekin N.N., Pekin D.A. Hidden Metal Capitals with Horizontal Sheet Reinforcement // Promyshlennoe i grazhdanskoe stroitel 'stvo, 2018, №6. - pp. 32-37.

9. Trekin N.N., Krylov V.V. On the question of the bearing capacity of reinforced concrete slabs for punching under dynamic loading on objects of ground-based space infrastructure // Nauchnyj aspekt, 2018, V. 7, № 4. - pp. 771-778.

10. Kabantsev O.V, Karlin A.V., Pesin K.O. Analysis of Stress-Strain State of Reinforced Concrete Plate Around Support Zones // International Journal for Computational Civil and Structural Engineering, 2017, 13 (1).-pp. $55-62$. 
Numerical Analysis of Longitudinal Reinforcement Effect on Rc Slab Punching Shear Resistance by Strength and Crack Propagation Criteria

11. Menetrey P. Numerical Analysis of Punching Failure in Reinforced Concrete Structures // Lausanne, EPFL. 1994. - p. 178.

12. Hueste Mery B.D., Browning J., Wallace J.W. Seismic Design Criteria for SlabColumn Connections // ACI Structural Jornal, 2007-08, Title № 104-S43. - pp. 448-458.

13. Muttoni A. Punching Shear Strength of Reinforced Concrete Slabs without Transverse Reinforcement // ACI Structural Jornal, 200808, Title № 105-S42. - pp. 440-450.

14. Bompa D.V., Onet T. An Incursion in Punching of Reinforced Concrete Flat Slabs // Universitatea Tehnica "Gheorghe Asachi" din Iasi Tomul LV (LIX), 2009, Fasc. 2.

15. Sacramento P.V.P., Federreira M.P., Oliveira D.R.C., Melo G.S.S.A. Punching Strength of Reinforced Concrete Flat Slabs Without Shear Reinforcement // Ibracon Structures and Materials Jornal, October 2012, V. 5, №5 - pp. 659-691. ISSN 1983-4195

16. Zhang X. Punching Shear Failure Analysis of Reinforced Concrete Flat Plates Using Simplified Ust Failure Criterion // School of Engineering Faculty of Engineering and Information Technology, December 2002. $141 \mathrm{p}$.

17. Tian Y. Behavior and Modeling of Reinforced Concrete Slabs-Column Connections (Dissertation Doctor of Philosophy) // The University of Texas at Austin, May 2007.

18. Cervenka V., Cervenka J., Kadlec L. Model uncertainties in numerical simulations of reinforced concrete structures // Structural Concrete, 2018. - pp. 1-13.

19. Cervenka V., Cervenka J., Gribniak V. Uncertainty of the smeared crack model applied to RC beams // Engineering Fracture Mechanics, 2020. - pp. 1-15.

20. Klovanich, S.F, Shekhovtsov V.I. Pressing of reinforced concrete slabs. Full-scale and numerical experiments // Odessa: ONMU, 2011. - p. 119.

21. Gvozdev, A.A., Zalesov, A.S., Ermuhanov K.E. Transitional forms between fracture along an inclined cross section and forcing //
Beton i zhelezobeton, Moscow, 1980, №3. pp. 27-29.

22. Zalesov A.S., Guntar V.A., Chizhevskii V.V. Border extrusion // Beton i zhelezobeton, Moscow, 1990, №2. - pp. 36-38.

23. Code of Regulations SP 63.13330.2018. Concrete and reinforced concrete structures. Basic provisions. Updated version of SNiP 52-01-2003, Moscow, Minregion Rossii., 2018. - p. 156

24. EN 1992-1-1:2004 Eurocode 2: Design of concrete structures - Part 1-1 : General rules and rules for buildings, Brussels: CEN, 2004.

25. fib Model Code for Concrete Structures 2010. fib Lausanne. Ernst\&Sohn, Switzerland, 2011.

26. Cervenka V., Jendele L., Cervenka J. ATENA Program Documentation. Part 1. Theory // Prague: Cervenka Consulting, 2020. - p. 344.

27. Zdenek P., Bazant B., Oh H. Crack band theory for fracture of concrete // Materials and Structures, 1983, V.16. - pp. 155-177.

28. Cervenka J., Cervenka V. On the uniqueness of numerical solutions of shear failure of deep concrete beams: comparison of smeared and discrete crack approaches //Computational Modeling of Concrete structures, 2010. - pp. 281-290.

29. Guandalini S., Burdet OL., Muttoni A. Punching tests of slabs with low reinforcement ratios // ACI Struct Journal, 2009. - pp. 87-95.

\section{СПИСОК ЛИТЕРАТУРЫ}

1. Лахтин Н.К., Кашкаров Н.А. Железобетон. Пособие в 3-х частях для студентов, инженеров и техников по проектированию и выполнению железобетонных сооружений. Часть III. Основания расчета железобетонных сооружений - М.: Государственное техническое издательство, 1925. - 161 с.

2. Залингер Р. Железобетон. Его расчет и проектирование. Издание пятое. Стереотипное - М.: Государственное научно-техническое издательство, 1931. - 671 с. 
3. Залесов А.С., Ермуханов К.Е., Качановский С.Г. Продавливание железобетонных плит. В кн. Исследования железобетонных конструкций при статических, повторных и динамических воздействиях - М.: НИИЖБ Госстроя СССР, 1984. - с. 17-22.

4. Залесов А.С., Ермуханов К.Е., Момбеков И.А. Прочность плит с поперечной арматурой на продавливание // Бетон и железобетон, 1990, №6. - с. 23-24.

5. Залесов А.С. Проектирование и расчет железобетонных монолитных зданий - М.: 2010. - 279 c.

6. Карпенко Н.И., Карпенко С.Н. Практическая методика расчета железобетонных плит на продавливание по различным схемам // Бетон и железобетон, 2012, №5. - с. 10-16.

7. Карпенко Н.И., Карпенко С.Н. К построению общей методики расчета железобетонных плит на продавливание с учетом влияния моментов // Вестник МГСУ, 2011, Т. 2, №3. - c. 86-91.

8. Трекин Н.Н., Пекин Д.А. Скрытые металлические капители с горизонтальной листовой арматурой // Промышленное и гражданское строительство, 2018, №6. - с. 32-37.

9. Трекин Н.Н., Крылов В.В. К вопросу о несущей способности железобетонных плит на продавливание при динамическом нагружении на объектах наземной космической инфраструктуры // Научный аспект, 2018, T. 7, № 4. - с. 771-778.

10. Кабанцев О.В, Карлин А.В., Песин К.О. Анализ напряженно-деформированного состояния плитных конструкций в приопорных зонах // International Journal for Computational Civil and Structural Engineering, 2017, 13 (1). - pp. 55-62.

11. Menetrey P. Numerical Analysis of Punching Failure in Reinforced Concrete Structures // Lausanne, EPFL. 1994. - p. 178.

12. Hueste Mery B. D., Browning J., Wallace J.W. Seismic Design Criteria for Slab-Column Connections // ACI Structural Jornal, 200708, Title № 104-S43. - pp. 448-458.
13. Muttoni A. Punching Shear Strength of Reinforced Concrete Slabs without Transverse Reinforcement // ACI Structural Jornal, 200808, Title № 105-S42. - pp. 440-450.

14. Bompa D.V., Onet T. An Incursion in Punching of Reinforced Concrete Flat Slabs // Universitatea Tehnica "Gheorghe Asachi" din Iasi Tomul LV (LIX), 2009, Fasc. 2.

15. Sacramento P.V.P., Federreira M.P., Oliveira D.R.C., Melo G.S.S.A. Punching Strength of Reinforced Concrete Flat Slabs Without Shear Reinforcement // Ibracon Structures and Materials Jornal, October 2012, V. 5, №5 - pp. 659-691. ISSN 1983-4195.

16. Zhang X. Punching Shear Failure Analysis of Reinforced Concrete Flat Plates Using Simplified Ust Failure Criterion // School of Engineering Faculty of Engineering and Information Technology, December 2002. - 141 p.

17. Tian Y. Behavior and Modeling of Reinforced Concrete Slabs-Column Connections (Dissertation Doctor of Philosophy) // The University of Texas at Austin, May 2007.

18. Cervenka V., Cervenka J., Kadlec L. Model uncertainties in numerical simulations of reinforced concrete structures // Structural Concrete, 2018. - pp. 1-13.

19. Cervenka V., Cervenka J., Gribniak V. Uncertainty of the smeared crack model applied to RC beams // Engineering Fracture Mechanics, 2020. - pp. 1-15.

20. Клованич С.Ф., Шеховцов В.И. Продавливание железобетонных плит. Натурный и численный эксперименты // Одесса: OHМУ, 2011. - 119 c.

21. Гвоздев А.А., Залесов А.С., Ермуханов К.Е. Переходные формы между разрушением по наклонному сечению и продавливанием // Бетон и железобетон, 1980, №3. - c. 27-29.

22. Залесов А.С., Гунтарь В.А., Чижевский В.В. Краевое продавливание // Бетон и железобетон, 1990, №2. - с. 36-38.

23. СП 63.13330.2018. Бетонные и железобетонные конструкции. Основные положения, М., 2018. 
Numerical Analysis of Longitudinal Reinforcement Effect on Rc Slab Punching Shear Resistance by Strength and Crack Propagation Criteria

24. EN 1992-1-1:2004 Eurocode 2: Design of concrete structures - Part 1-1 : General rules and rules for buildings, Brussels: CEN, 2004.

25. Fib Model Code for Concrete Structures 2010. fib Lausanne. Ernst\&Sohn, Switzerland, 2011.

26. Cervenka V., Jendele L., Cervenka J. ATENA Program Documentation. Part 1. Theory // Prague: Cervenka Consulting, 2020. - p. 344.

27. Zdenek P., Bazant B., Oh H. Crack band theory for fracture of concrete // Materials and Structures, 1983, V.16. - pp. 155-177.
28. Cervenka J., Cervenka V. On the uniqueness of numerical solutions of shear failure of deep concrete beams: comparison of smeared and discrete crack approaches //Computational Modeling of Concrete structures, 2010. - pp. 281-290.

29. Guandalini S., Burdet OL., Muttoni A. Punching tests of slabs with low reinforcement ratios // ACI Struct Journal, 2009. - pp. 87-95.
Oleg V. Kabantsev, Dr.Sc.; Professor of the Department of Reinforced Concrete and Stone Structures National Research Moscow State University of Civil Engineering; 26, Yaroslavskoe Shosse, Moscow, 129337, Russia; phone: +; Email: ovk531@gmail.com.

Sergey B. Krylov, corresponding member of the Russian Academy of Architecture and Construction Sciences, Dr.Sc.; Head of the Laboratory of Reinforced Concrete Mechanics of Research Institute of Concrete and Reinforced Concrete (NIIZHB) named after A.A. Gvozdev, JSC Research Center of Construction; 6, 2nd Institutskaya, Moscow, 109428, Russia; phone: +7(499) 174-74-07; Email: niizhb_lab8@mail.ru.

Sergey V. Trofimov, master's student of National Research Moscow State University of Civil Engineering; engineer of Reinforced Concrete Mechanics of Research Institute of Concrete and Reinforced Concrete (NIIZHB) named after A.A. Gvozdev, JSC Research Center of Construction; 26, Yaroslavskoe Shosse, Moscow, 129337, Russia; Email: serkeypro@yandex.ru.
Кабанцев Олег Васильевич, доктор технических наук; профессор кафедры железобетонных и каменных конструкций Национального исследовательского Московского государственного строительного университета; 129337, Россия, г. Москва, Ярославское шоссе, дом 26; телефон: + ;Email: ovk531@gmail.com.

Крылов Сергей Борисович, член-корреспондент РААСН, доктор технических наук; заведующий лаборатории №8 «Механики железобетона» НИИЖБ им. А.А. Гвоздева АО «НИЦ «Строительство»; 109428, Россия, г. Москва, 2-я Институтская улица, дом 6, корпус 5; телефон: +7(499) 174-74-07; Email: niizhb_lab8@mail.ru.

Трофимов Сергей Владиславович, магистрант Национального исследовательского Московского государственного строительного университета; инженер лаборатории №8 «Механики железобетона» НИИЖБ им. А.А. Гвоздева АО «НИЦ «Строительство»; 129337, Россия, г. Москва, Ярославское шоссе, дом 26; Email: serkeypro@yandex.ru. 